\title{
Radicular dysfunction preponderance at early phase clinical evaluation in myelitis by Schistosoma mansoni
}

\author{
Claudio Henrique Fernandes Vidal1,2, Joacil Carlos da Silva 1,2, \\ Jefferson Jane Oliveira Souza², Sara Pimentel Belleza Bernardino3 \\ Maria Lucia Brito Ferreira ${ }^{4}$
}

\begin{abstract}
In neuroschistosomiasis, the spinal cord is the most common place of the disease. In high prevalent areas for schistosomiasis mansoni, the clinical alertness is important for an early diagnostic, in order to decrease the final neurological damage. This study provides some useful neurologic information about a series of patients with schistosomal myelitis. Method: The sample consisted of 13 schistosomiasis mansoni carriers examined at the moment of the diagnosis of myelitis. Results: The classical triad (lumbago, weakness at the lower limbs and urinary dysfunctions) was documented in 11 (86.61\%) patients. The distribution of the clinical forms was: myeloradicular in six patients (46.15\%), radicular in four (30.76\%) and myelitic in three (23.07\%). Conclusion: The radicular dysfunction and their clinical associated forms were the most prominent pattern during the early phase of this disease.
\end{abstract}

Key words: schistosomiasis mansoni, neuroschistosomiasis, myelitis, neurologic examination, medical history taking.

\section{Preponderância de disfunções radiculares na avaliação clínica precoce da mielite pelo Schistosoma mansoni}

\section{RESUMO}

Na neuroesquistossomose, a medula espinhal é o sítio de predileção da doença. Em áreas de alta prevalência para esquistossomose mansoni, o conhecimento clínico dessa condição é importante para o seu diagnóstico precoce e consequente redução da lesão neurológica definitiva. Este estudo provê informações neurológicas relevantes pertinentes a uma série clínica de pacientes com mielite esquistossomótica. Método: A amostra consistiu de 13 pacientes portadores de esquistossomose mansoni examinados no momento do diagnóstico de sua forma mielítica. Resultados: A tríade clássica (lombalgia, fraqueza nos membros inferiores e disfunções urinárias) foi documentada em 11 (86,61\%) pacientes. Quanto à distribuição das formas clínicas, se observou a ocorrência da mieloradicular em seis pacientes $(46,15 \%)$, da radicular em quatro $(30,76 \%)$ pacientes e da mielítica em três (23,07\%) pacientes. Conclusão: A disfunção radicular e suas formas clínicas associadas foram o padrão mais frequente durante a avaliação na fase precoce da doença. Palavras-chave: esquistossomose mansoni, neuroesquistossomose, mielite, exame neurológico, anamnese.

\section{Correspondence}

Claudio Henrique F. Vidal

Rua Francisco da Cunha 206

51020-041 Recife PE - Brasil

E-mail: vidal-claudio@ig.com.br

Received 6 July 2010

Received in final form 3 October 2010

Accepted 14 October 2010
Schistosomiasis is one of the older and more diffused parasitic diseases of the world, and nowadays represents a se- rious public health problem. It is endemic in more than 74 countries, and is responsible for the majority of the cases of portal

'Departamento de Pós-graduação em Neuropsiquiatria e Ciências Comportamentais do Centro de Ciências da Saúde da Universidade Federal de Pernambuco (UFPE), Recife PE, Brazil; ${ }^{2}$ Neurosurgeon; ${ }^{3}$ Resident of Neurology; ${ }^{4}$ Head of Neurology, Hospital da Restauração, Recife PE, Brazil. 
hypertension among the young population. Around the world, it is believed that there are 200 million people infected by the specimens mansoni, haematobium, japonicum, intercalatum or mekong ${ }^{1,2}$.

In neuroschistosomiasis, the spinal cord is the most common place of the disease ${ }^{3}$. The exact frequency of myelopathy in these patients has never been properly studied, in part because of the wide variations in clinical expression ${ }^{4}$. Nowadays, neuroschistosomiasis is considered the third most common cause of myelopathy, after traumatic and tumor involvements ${ }^{5,6}$.

Originally from the African continent, Schistosoma mansoni (SM) was brought to Brazil during the slavery period, and found favorable weather conditions and a large number of hosts for its proliferation. Currently, bad sanitary conditions in Brazil perpetuate the endemic status of this severe parasitic disease ${ }^{2}$.

The first reference to myelitis by $S M$ was made in 1930 when a German citizen that lived in Brazil developed spinal cord affection at the thoracic and lumbar levels. The necropsy study showed eggs of SM. In 1945, Gama registered the first case of schistosomal myelitis in the Brazilian medical literature, and the diagnosis was made by the histopathological study of surgical tissue. In 1956, Martinez recommended a high level of suspicion in cases of transverse myelitis that came from endemic zones for SM. In 1964, Oliveira classified the disease in three different syndromes: pseudotumoral spinal cord compression, myeloradiculopathy and myelobulbar, apud Santos?.

In high prevalent areas for schistosomiasis, clinical alertness and the use of pertinent exams for the diagnosis must be performed as soon as possible, for all patients with complaints of: acute or subacute lumbago, paresthesic sensation at the lower limbs and urinary dysfunction $^{3,4,8}$. The physical exam can reveal motor deficit in lower limbs and altered sensation on dermatomes of lumbosacral roots.

The recent advances in neurological radiology and in immunology have increased the knowledge of the physiopathology and clinical aspects of this intriguing condition. Therefore, this diagnosis has become more frequent ${ }^{8}$. This study adds information about the clinical exam of patients with the spinal form of schistosomiasis at the moment of the development of their symptoms.

\section{METHOD}

The study protocol was approved by the institutional review board of the participating center (Hospital da Restauração, CAAE- 0033.0.102.172-05) and patients gave written consent for data analysis.

This study was a sectional and descriptive evaluation (in a series of cases), from a hospital base, where the sample consisted of schistosomiasis mansoni carriers at the moment of the diagnosis of myelitis. The patients were hospitalized in the neurological infirmary between July 2005 and June 2006.

The authors used as inclusion criteria, the recommendations for diagnosis from the Centers for Disease Control $(\mathrm{CDC})^{9}$ : dysfunction of thoracic or lumbosacral spinal cord; parasitological confirmation of the infection by $S M$ and exclusion of other causes for transversal myelitis.

The neurological form of the disease was defined by some clinical findings during examination. For the spinal cord form, the features considered were: symmetry of the deficits, hyperactive deeper tendon reflex, and definition of a sensitive or motor spinal level. The radicular forms were considered when the motor deficits were asymmetric, deeper tendon reflex was decreased or absent, and with radicular (in distribution) sensitive deficits.

\section{RESULTS}

A total of 13 patients were evaluated during the period of study. The anamnesis data are shown in Table 1. The classical triad (lumbago, weakness at the lower limbs and urinary dysfunctions) was documented in 11 (86.61\%) patients.

The results of the physical examination of the patients are shown in Table 2. Whatever the motor deficits, in six cases (46.15\%) they were considered symmetric, and asymmetric in the others (seven cases - 53.84\%). Sellar sensitive alterations occurred in nine (69.23\%) patients.

Concerning the clinical forms, they are described in Table 3.

Table 1. Anamnesis data of the patients.

\begin{tabular}{lcc}
\hline Clinical data & $\mathbf{n}$ & $\%$ \\
\hline Gender & 7 & 53.84 \\
$\quad$ Male & 6 & 46.15 \\
$\quad$ Female & & \\
Age (years old) & 27.31 & \\
$\quad$ Mean & 15 & \\
Minimal & 47 & \\
Maximum & 12 & 92.30 \\
Positive epidemiology & & \\
Symptoms & 12 & 92.30 \\
Lumbago & 11 & 84.61 \\
Paresthesias & 13 & 100 \\
Urinary dysfunctions & 13 & 100 \\
Lower limb weakness & 12 & 92.30 \\
Intestinal dysfunctions & 5 & 38.46 \\
Previous physical effort & & \\
\hline
\end{tabular}


Table 2. Physical examination of the patients.

\begin{tabular}{lcc}
\hline Physical exam & $\mathrm{n}$ & $\%$ \\
\hline Motor déficits & 2 & 15.38 \\
$\quad$ Paraplegic & 4 & 30.76 \\
$\quad$ Distal paraparesis & 6 & 46.15 \\
Proximal paraparesis & 1 & 7.69 \\
Monoparesis & & \\
Sensitive pattern & 8 & 61.54 \\
$\quad$ Radicular & 3 & 23.08 \\
$\quad$ Sentive level & & \\
Objective sensibility & 9 & 69.23 \\
$\quad$ Hipoestesia & 4 & 30.76 \\
$\quad$ Disestesia & & \\
Patellar reflex & 8 & 61.53 \\
$\quad$ Decreased or absent & & 38.46 \\
Increased & 5 & \\
Achilles reflex & & 3.69 \\
$\quad$ Decreased or absent & 7 & 38.46 \\
Normal & 1 & \\
Increased & 5 & \\
\hline
\end{tabular}

Table 3. Clinical forms of schistosomal myelitis.

\begin{tabular}{lcc}
\hline Clinical forms & $\mathbf{n}$ & $\%$ \\
\hline Radicular & 4 & 30.76 \\
Myeloradicular & 6 & 46.15 \\
Myelitic & 3 & 23.07 \\
Pseudotumoral & 0 & 0 \\
\hline
\end{tabular}

\section{DISCUSSION}

The distribution, whatever the gender, was very similar (53.84\% of males and $46.15 \%$ of females), and diverges from the literature, that refers to men a greater risk of acquiring this condition. This occurs because of social and economic factors as recreational activities and heavy work, and consequently a higher frequency of physical efforts, that cause higher levels of abdominal inner pressure ${ }^{4,8,10}$.

The mean age was 27.31 years (ranging from 15 to 47 years). These results are in accordance with other reports ${ }^{3,7}$, and reflect the most prevalent age for schistosomiasis (between 10 and 40 years of age) ${ }^{11}$. These young individuals usually are more exposed to infected waters, moreover they usually are involved in more physical activities, and therefore are more susceptible to higher abdominal inner pressure and eggs migration.

A positive epidemiological history for schistosomiasis was present in 12 (92.3\%) patients, and this was defined by the contact with natural reservoirs. Eight (61.53\%) pa- tients had had direct contact with the snail (Biomphalaria). The only case that didn't fulfill this criterion came from a high prevalent zone for this disease (Forest zone - Zona da Mata- of Pernambuco State), and had the classical clinical picture with parasitic confirmation in stools and positive reactions for schistosomiasis in the cerebrospinal fluid. These data are difficult to confront with the ones of other series, because they usually are not shown.

In the anamnesis, all the patients had complaints of weakness of the lower limbs and urinary dysfunction. These symptoms have been considered very typical of this disease $e^{4}$. Urinary retention was found in 12 (92.3\%) of the patients and was attributed to damage at the conus medullaris (mictional center), cauda equine (afferent and efferent pathways) or just efferent pathways. The two former situations are called autonomic bladder and the last one, motor-paralytic bladder. One of the patients showed urinary incontinence (by reflex bladder), and this patient had a pure spinal cord form of the disease. There was a high occurrence of fecal retention (92.3\% of the cases). Similar data was supported by Correia $^{12}$ and Asano's ${ }^{13}$ casuistic in which sphincters symptoms were the most prevalent.

Lumbago was described in 12 (92.3\%) of the cases, and this was in accordance with the literature consulted, that described this symptom from $72.2 \%$ up to $100 \%$ of the patients ${ }^{3,4,10,12,14,15}$. The classical triad of complaints (lumbago, urinary dysfunction and paresthesias in lower limbs), was identified in 11 (84.61\%) patients in the present study. Peregrino et al., ${ }^{3,8}$ emphasized the necessity that health care professionals that work in endemic zones for schistosomiasis be familiarized with these complaints. This surveillance would promote an early diagnosis, and probably would decrease the occurrence of definitive neurological damage.

The motor exam revealed that two (15.38\%) patients were paraplegic, and four (30.77\%) had predominant distal paraparesis whereas six (46.15\%), had predominant proximal paraparesis. Crural monoparesis was observed in just one (7.69\%) patient. Thus, there were 10 paraparetic patients, of whom six (60\%) had proximal deficit and four $(40 \%)$ had distal deficit. In six cases (46.15\%) the deficits were considered symmetric, and in the other seven cases (53.84\%) asymmetric. An equivalent amount of paraparetic patients was reported by Santos et al. ${ }^{4}$, but all those patients had a distal and symmetric distribution. These patterns diverge from the present report. Maybe a proximal and asymmetric distribution, as it occurred in our patients, can be better associated with the multi-radicular compromising usually observed in schistosomal myelitis.

Whatever the deep tendon reflex, patellar and Achilles reflex were decreased or absent in 8 (61.53\%) and in 7 (53.84\%) of the patients, respectively. They were 
increased in 5 (38.46\%) patients for each reflex. Santos et al. ${ }^{4}$ found similar results in their analyses. Instead of high spinal cord involvement detected in an MRI during this study (12 patients, 92.3\%), the long pathways dysfunction was blunted during clinical evaluation, probably by concomitant radicular involvement (46.15\% of the myeloradicular form and $30.76 \%$ of just the radicular form). Another finding was the short period of time between the beginning of the symptoms and the neurological exam. This may explain the low expression of liberation pyramidal signs. We believe that this brief evolution also justifies the absence of pseudotumoral forms.

The sensitive disturbances were: deficitary syndrome (hypoesthesia) in 9 (69.23\%) cases, and irritative syndromes like paresthesias in $4(30.76 \%)$. A pure spinal cord sensitive level could just be defined in 3 (23.08\%) cases, whereas in the remaining, some radicular patterns were observed which is in accordance with Galvão ${ }^{10}$ data. Sellar sensitive alterations occurred in $9(69.23 \%) \mathrm{pa-}$ tients, corroborating the high index of dysfunction at the conus medullaris and cauda equine.

The myelitic form of the disease was observed in just 3 (23.07\%) of the patients, and the myeloradicular form was present in $6(46.15 \%)$ cases. A pure radicular form was documented in $4(30.76 \%)$ patients. The pseudotumoral form wasn't present in the current study. Peregrino et al. ${ }^{8}$ and $\mathrm{Asano}^{13}$ reported the myeloradicular form in $72.5 \%$ and $96.5 \%$ of their patients, respectively. Probably in these series, the clinical neurological evaluation was done in a moment that the signals of liberation of the superior motor neuron dysfunction, dominated the clinical setting.

In a survey of the literature available until 2001, Santos et al. ${ }^{4}$ catalogued the following distribution: myeloradicular (71 cases/44.4\%), myelitic (44 cases/27.5\%) and pseudotumoral (39 cases/24.4\%). These results are closer to the findings of the present study. Valença, Barros and Ataíde ${ }^{16}$ after analyses of 60 cases, observed that the myelitic form was preponderant (62\%), but the signals of motor neuron compromising (radicular) were also common, especially during the acute phase of the disease.
The nature of this study (sectional) forbids any inference about the course of the clinical manifestations over time. Probably in a coorte study, the sample might change their findings during the illness, with the radicular pattern being more common at an early phase of the neuroschistosomiasis and myelitic features might preponderate at a late phase.

\section{REFERENCES}

1. Doumenge JP. Atlas de la répartition mondiale des schistosomiasis. Genève: OMS/WHO; 1987.

2. Coutinho AD, Domingues ALC. Esquistossomose mansoni. In: Dani R, Castro LP (Eds). Gastroenterologia clínica. Rio de Janeiro: Guanabara Koogan; 1993:1697-1728.

3. Peregrino AJP, Oliveira SP, Porto CA, et al. Meningomielorradiculite por Shistosoma mansoni: protocolo de investigação e registro de 21 casos. Arq Neuropsiquiatr 1988;46:49-60.

4. Santos EC, Campos GB, Diniz AC, Leal JC, Rocha MOC. Perfil clínico e critérios diagnósticos da mielorradiculopatia esquistossomótica. Arq Neuropsiquiatr 2001;59:772-777.

5. Spina-França A, Salum PNB, Limongi JCP, Berger A, Losso ER. Mielopatias: aspectos diagnósticos. Arq Neuropsiquiatr 1980;38:360-366.

6. Brito JCF, Nóbrega PV. Mielopatias: considerações clínicas e aspectos etiológicos. Arq Neuropsiquiatr 2003;61: 816-821.

7. Santos EC. Perfil diagnóstico da mielorradiculopatia esquistossomótica em três hospitais de Belo Horizonte: estudo retrospectivo - 1972 a 1992. [Dissertação Mestrado]. Belo Horizonte: Faculdade de Medicina da Universidade Federal de Minas Gerais; 1994.

8. Peregrino AJP, Puglia PMK, Nóbrega JPS, Livramento JA, Marques-Dias MJ, Scaff M. Esquistossomose medular: análise de 80 casos. Arq Neuropsiquiatr 2002;60:603-608.

9. Centers for Disease Control and Prevention: acute schistosomiasis with transverse myelitis in American students returning from Kenya [editorial note]. Morb Mortal Wkly Rep 1984;33:446-447.

10. Galvão ACR. Milelopatias esquistossomóticas; aspectos clínicos e laboratoriais. [Dissertação de Mestrado]. São Paulo: Faculdade de Medicina da Universidade de São Paulo; 1983

11. Raso P. Esquistossomose Mansônica. In: Filho GB (Ed). Bogliolo Patologia. Rio de Janeiro: Editora Guanabara Kookan SA; 2000:1186-1207.

12. Correia CC. Aspectos clínicos, eletromiográficos e de evolução de pacientes com neuroesquistossomose. [Dissertação de Mestrado]. Recife: Faculdade de Medicina da Universidade de Pernambuco; 2004

13. Asano NMJ. Neuroesquistossomose: Aspectos clínicos, laboratoriais e de imunodiagnóstico. [Dissertação de Mestrado]. Recife: Faculdade de Medicina da Universidade Federal de Pernambuco; 1992.

14. Ferrari TCA, Moreira PRR, Ferrari MLA, et al. Clinical and immunological study of schistomal myelorradiculopathy. Ann Trop Med Parasitol 1993;87:295-297.

15. Costa RO, Gameleira FT, Tenório RB, Bras LH, Costa VB, Jr JMP. Neuroesquistossomose em Alagoas. Rev Bras Neurol 1992;28:79-84.

16. Valença MM, Barros AC, AtaídeJr L. Neuroesquistossomose: aspectos epidemiológicos e critérios diagnósticos. Neurobiologia 1992;55:145-152. 